\title{
THE AUTOBIOGRAPHY
}

\author{
or \\ ANNE LADY HALKETT.
}

EDTTED BY

JOHN GOUGH NICHOLS, F.S.A., \&c.

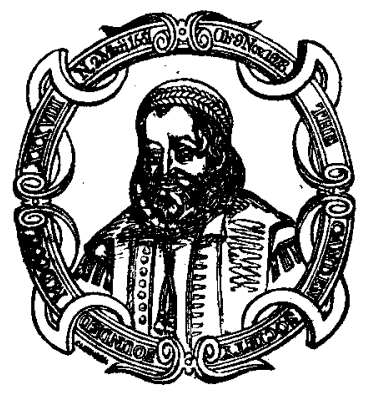

PRINTED FOR THE CAMDEN SOCIETY.

M.DCcC.LXXV. 
WEETMLNGTER :

PRINTED BY NICHOLS AND SONS,

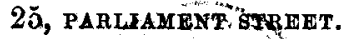

[NEW SERIES XIII.] 


\section{COUNCIL OF TIIE CAUDEN SOCIETY}

FOR THE YEAR 1875-76.

\section{President,}

THE RIGHT HON. THE EARL OF VERULAM, F.R.l.S.

WILLIAM CHAPPELL, ESQ. F.S.A., Treasurer.

WILLIAM DURRANT COOPER, ESQ. F.S.A.

HENRY CHARLES COOTE, ESQ. F.S.A.

JAMES GAIRDNER. ESQ.

SAMUEL RAWSON GARDINER, ESQ., Directer.

WILLIAM GILBERT, FSQ.

FRANK SCOTT HAYDON, ESQ.

WILLIAM OXENHAM HEWLETT, ESQ.

ALFRED KINGSTON, ESQ., Secretary.

SIR JOHN MACLEAN, F.S.A.

FREDERIC OUVRY, ESQ. V.P. S.A.

REV. W. SPARROW SIMPSON, D.D. F.S.A.

JAMES SPEDDING, ESQ.

WILLIAM JOHN THOMS, ESQ. F.S.A.

J. R. DANIEL-TYSSEN, ESQ. F.S.A. 
The Council of the Camben Soctety desire it to be understood that they are not answerable for any opinions or observations that may appear in the Society's publications; the Fditors of the several Works being alone responsible for the same. 